\title{
Loss of ERß expression as a common step in estrogen-dependent tumor progression
}

\author{
A Bardin ${ }^{1}, N$ Boulle $^{1,2}$, G Lazennec $^{1}, F$ Vignon $^{1}$ and P Pujol ${ }^{1,2}$ \\ ${ }^{1}$ Unité INSERM 540, 60 rue de Navacelles, 34090 Montpellier, France \\ ${ }^{2}$ Laboratoire de Biologie Cellulaire, Centre Hospitalier Universitaire de Montpellier, Hôpital Arnaud de \\ Villeneuve, 271, Av G. Giraud, 34295 Montpellier, France \\ (Requests for offprints should be addressed to P Pujol, Service de Biologie Cellulaire, Hôpital Arnaud de Villeneuve, CHU, 271, Av G. Giraud, \\ 34295 Montpellier, France; Email: p-pujol@ chu-montpellier.fr)
}

\begin{abstract}
The characterization of estrogen receptor beta $(E R \beta)$ brought new insight into the mechanisms underlying estrogen signaling. Estrogen induction of cell proliferation is a crucial step in carcinogenesis of gynecologic target tissues, and the mitogenic effects of estrogen in these tissues (such as breast, endometrium and ovary) are well documented both in vitro and in vivo. There is also an emerging body of evidence that colon and prostate cancer growth is influenced by estrogens. In all of these tissues, most studies have shown decreased ER $\beta$ expression in cancer as compared with benign tumors or normal tissues, whereas ER $\alpha$ expression persists. The loss of ER $\beta$ expression in cancer cells could reflect tumor cell dedifferentiation but may also represent a critical stage in estrogen-dependent tumor progression. Modulation of the expression of ER $\alpha$ target genes by ER $\beta$ or ER $\beta$-specific gene induction could explain that $E R \beta$ has a differential effect on proliferation as compared with $E R \alpha$. $E R \beta$ may exert a protective effect and thus constitute a new target for hormone therapy, such as ligand specific activation. The potential distinct roles of $E R \alpha$ and $E R \beta$ expression in carcinogenesis, as suggested by experimental and clinical data, are discussed in this review.
\end{abstract}

Endocrine-Related Cancer (2004) 11 537-551

\section{Introduction}

It is well documented that the mitogenic actions of estrogens are critical in the etiology and progression of human breast and gynecologic cancers (Henderson et al. 1988, Pike et al. 1993). The promoting effect of estrogens was recently highlighted by the results of large prospective studies, showing that estradiol intake during menopause increased the risk of breast cancer (BC) (Nelson et al. 2002, Rossouw et al. 2002, Beral et al. 2003, Chlebowski et al. 2003). In ovarian cancer, although the question is still debated (Coughlin et al. 2000), several recent prospective studies have indicated a risk of ovarian cancer for women undergoing long-term estrogen replacement therapy (Rodriguez et al. 2001, Lacey et al. 2002, Anderson et al. 2003, Folsom et al. 2004). In contrast, estrogens appear to exert a protective effect on the risk of colon cancer (Rossouw et al. 2002).

The effects of estrogens are mediated by estrogen receptor (ER) $\alpha$ and ER $\beta$, which are members of the nuclear steroid receptor superfamily. ER $\alpha$ and ER $\beta$ classically mediate their action by ligand-dependent binding to the estrogen-response element (ERE) of target genes, leading to their transcription regulation (Green et al. 1986, Kuiper et al. 1996, Mosselman et al. 1996, Tremblay et al. 1997). Both of these proteins have a high degree of homology in the DNA-binding domain (Mosselman et al. 1996), but differ considerably in the N-terminal domain and to a lesser extent in the ligand-binding domain (E domain) (Kuiper et al. 1996, Mosselman et al. 1996). These differences suggest that the two receptors could have distinct functions in terms of gene regulation and biologic responses and may contribute to the selective actions of 17- $\beta$-estradiol (E2) in different target tissues (Gustafsson \& Warner 2000).

Recently, various studies have shown decreased expression of ER $\beta$ mRNA and protein (or an increased $\mathrm{ER} \alpha / \mathrm{ER} \beta$ mRNA ratio) in tumor versus normal tissues in many cancers, including breast, ovary, colon and prostate 
(Brandenberger et al. 1998, Pujol et al. 1998, Foley et al. 2000, Rutherford et al. 2000, Campbell-Thompson et al. 2001, Roger et al. 2001, Fixemer et al. 2003). The ER $\alpha /$ $\mathrm{ER} \beta$ gene expression ratio thus appears to increase during carcinogenesis, suggesting that ER $\alpha$ - and ER $\beta$-specific pathways may have distinct roles in this process (Leygue et al. 1998). The differential expression of ER $\alpha$ and ER $\beta$ in cancer cells and experimental data on their respective roles on proliferation are reviewed in this report.

\section{Differential ER $\beta$ expression as a common feature of estrogen-dependent tumor progression in clinical studies}

\section{Analysis of ER $\alpha$ and ER $\beta$ expression in estrogen-sensitive cancers (Tables 1-4)}

In breast tissues, several studies have indicated an increase in $\mathrm{ER} \alpha / \mathrm{ER} \beta \mathrm{mRNA}$ and protein ratios in cancer as compared with benign tumors and normal tissues. In immunochemical analyses, Roger et al. (2001) found a higher percentage of ER $\beta$-positive cells in normal mammary glands than in nonproliferative benign breast disease (BBD) $(85 \%)$, proliferative BBD without atypia $(18.5 \%)$ and carcinoma in situ $(33.8 \%)$. In contrast, an increase in $\mathrm{ER} \alpha$ protein expression was noted during progression. Moreover, ER $\beta$ was inversely correlated with Ki67, a marker of cell proliferation. The authors thus suggest that ER $\beta$ protects against the mitogenic activity of estrogens in mammary premalignant lesions. This conclusion is also supported by the results of another study (Shaw et al. 2002), which revealed lower ER $\beta$ protein expression in carcinomas and demonstrated that $\mathrm{ER} \alpha$, but not ER $\beta$, protein expression was correlated with tumor grade. Similar findings were obtained at the mRNA level by the RT-PCR method by Iwao et al. (2000), who also showed that ER $\alpha$ mRNA is increased and ER $\beta$ mRNA decreased during breast carcinogenesis. Recently, Park et al. (2003) compared ER $\beta$ mRNA levels in various breast tissues, using mRNA in situ hybridization. ER $\beta$ expression was decreased in $\mathrm{BC}$ and metastatic lymph node tissues as compared with normal mammary and benign breast tumor (BBT) tissues. The intensity and extent of ER $\beta$ expression were significantly higher in normal and BBT tissues than in BC or metastatic lymph node tissues (Park et al. 2003).

In invasive $\mathrm{BC}$, other studies using immunohistochemistry (IHC) and in situ hybridization revealed that ER $\beta$ expression was associated with indicators of low biologic aggressiveness (low tumor grade, low S-fraction and negative lymph node status), suggesting that ER $\beta$ might be a good prognostic indicator (Jarvinen et al. 2000). Omoto et al. (2001) in a survival analysis showed that patients with ER $\beta$-positive tumors had increased disease-free survival at 5 years as compared with those with ER $\beta$-negative tumors. Fuqua et al. (2003) studied ER $\beta$ expression using IHC in a pilot series of 242 BC patients and showed that ER $\beta$ expression is not associated with clinical and biologic parameters, including progesterone receptor (PR) expression, tumor grade and S-phase fraction. ER $\beta$ was found to be correlated only with aneuploidy. The findings of this study suggested that ER $\beta$ could be a useful biomarker on its own in clinical breast tumors. To gain insight into the possible role of ER $\beta$ in breast carcinogenesis, Skliris et al. (2003) did an IHC analysis of ER $\beta$ in 512 breast specimens. Moreover, realtime PCR was used to investigate the ER $\beta$ gene methylation status in the ER $\beta$-negative $B C$ cell lines SK-BR-3 and MDA-MB-435. The results suggested that the loss of ER $\beta$ expression is one of the hallmarks of breast carcinogenesis, and that it may be a reversible process involving methylation. Zhao et al. (2003) also concluded that decreased ER $\beta$ mRNA expression may be associated with breast tumorigenesis and that DNA methylation is an important mechanism for ER $\beta$ gene silencing in BC (Table 1). Collectively, ER $\beta$ expression decreases in the process of $\mathrm{BC}$ development.

The ovary (Table 2) contains both ER isoforms, but ER $\beta$ seems to be the predominant species expressed in normal ovary in rats (Byers et al. 1997) and humans (Kuiper et al. 1996, Enmark et al. 1997). Our laboratory (Pujol et al. 1998) documented an increase in the ER $\alpha$ / ER $\beta$ mRNA ratio in ovarian carcinomas as compared with normal ovaries and cysts, and our findings suggested that overexpression of $\mathrm{ER} \alpha$ relative to $\mathrm{ER} \beta$ mRNA may be a marker of ovarian carcinogenesis. This conclusion was further supported by Brandenberger et al. (1998) and Rutherford et al. (2000). The latter revealed that the balance between $\mathrm{ER} \alpha$ and $\mathrm{ER} \beta$ receptors might be essential for maintaining normal cellular function, suggesting that, as ER $\beta$ decreases, uncontrolled cellular proliferation leads to a metastatic state. Lau et al. (1999) found no differences in ER $\beta$ mRNA expression between normal and cancer epithelial cells, but these authors analyzed only a few HOSE cell primary cultures $(n=4)$ and ovarian cancer cell lines $(n=3)$ by a nonquantitative PCR method. Decreasing levels of ER $\beta$ expression seem to be a common denominator between breast and ovarian carcinogenesis.

In prostate, it has been suggested that estrogens and their receptors may be involved in cancer development and progression (Santti et al. 1994, Farnsworth et al. 1999, Jarred et al. 2000). Estrogen exposure during prostate development may initiate cellular processes resulting in future neoplasia (Santti et al. 1994). In a study of Latil et al. (2001), ER $\alpha$ and $E R \beta$ mRNA expression was quantified by real-time RT-PCR in both benign and malignant prostate. 
Table 1 Relative expression of ER $\alpha$ and ER $\beta$ in breast tumor progression

\begin{tabular}{|c|c|c|c|c|c|c|c|c|}
\hline \multirow{2}{*}{ References } & \multirow{2}{*}{ Tissues } & \multirow{2}{*}{ Number } & \multirow{2}{*}{ Methods } & \multirow{2}{*}{$\frac{\mathrm{ER} \alpha}{\mathrm{SQ} \mathrm{Ov}}$} & & \multirow{2}{*}{$\frac{\mathrm{ER} \beta}{\mathrm{SQ} \mathrm{Ov}}$} & & \multirow{2}{*}{ Comments } \\
\hline & & & & & & & & \\
\hline $\begin{array}{l}\text { Roger et al. } \\
(2001)\end{array}$ & $\begin{array}{l}\text { Normal } \\
\text { NP-BBD } \\
\text { P-BBD } \\
\text { P-BBDWA } \\
\text { CIS } \\
\text { High-grade CIS }\end{array}$ & $\begin{array}{r}118 \\
18 \\
37 \\
13 \\
25 \\
35\end{array}$ & $\mathrm{IHC}$ & $\begin{array}{c}+ \\
+ \\
++ \\
++ \\
++ \\
++\end{array}$ & $\uparrow$ & $\begin{array}{l}+++ \\
++ \\
++ \\
+ \\
+ \\
-\end{array}$ & $\downarrow \downarrow$ & $\begin{array}{l}\text { ER } \beta \text { positive } \\
\text { Cells decrease during } \\
\text { preinvasive tumor progression }\end{array}$ \\
\hline $\begin{array}{l}\text { Iwao et al. } \\
(2000)\end{array}$ & $\begin{array}{l}\text { Normal } \\
\text { Cancer }\end{array}$ & $\begin{array}{r}11 \\
112\end{array}$ & Real-time-PCR & $\begin{array}{c}++ \\
+++\end{array}$ & $\uparrow$ & $\begin{array}{l}+++ \\
++\end{array}$ & $\downarrow$ & $\begin{array}{l}\text { Changes in ER } \beta 1 \text { and ER } \beta 2 \text { mRNA } \\
\text { levels in breast cancer }\end{array}$ \\
\hline $\begin{array}{l}\text { Park et al. } \\
(2003)\end{array}$ & $\begin{array}{l}\text { Normal } \\
\text { BBT } \\
\text { Breast cancer } \\
\text { Met. lymph node }\end{array}$ & $\begin{array}{l}89 \\
11 \\
85 \\
10\end{array}$ & ISH & 1 & & $\begin{array}{l}+++ \\
+++ \\
+ \\
+\end{array}$ & $\downarrow$ & $\begin{array}{l}\text { ER } \beta \text { mRNA level decreases during } \\
\text { tumor progression } \\
\text { High ER } \beta \text { level associated with } \\
\text { poor differentiation }\end{array}$ \\
\hline $\begin{array}{l}\text { Skliris et al. } \\
\text { (2003) }\end{array}$ & $\begin{array}{l}\text { Normal } \\
\text { PDCIS } \\
\text { Invasive cancers } \\
\text { Met. lymph node } \\
\text { Recurrences }\end{array}$ & $\begin{array}{r}138 \\
16 \\
319 \\
31 \\
8\end{array}$ & $\mathrm{IHC}$ & I & & $\begin{array}{l}++++ \\
+++ \\
++ \\
+ \\
+\end{array}$ & $\downarrow$ & $\begin{array}{l}\text { Reduced expression of ER } \beta \\
\text { in invasive breast cancer } \\
\text { Loss of ER } \beta \text { may be a reversible } \\
\text { process involving methylation }\end{array}$ \\
\hline $\begin{array}{l}\text { Speirs et al. } \\
(1999)\end{array}$ & $\begin{array}{l}\text { Normal } \\
\text { Cancer }\end{array}$ & $\begin{array}{l}23 \\
60\end{array}$ & RT-PCR & $\begin{array}{c}+ \\
+++\end{array}$ & $\uparrow$ & $\begin{array}{l}+++ \\
+\end{array}$ & $\downarrow \downarrow$ & $\begin{array}{l}22 \% \text { of normal breast expressing } \\
\text { exclusively ER } \beta \text { mRNA } \\
50 \% \text { of breast tumors coexpressing } \\
\text { ER } \alpha \text { and ER } \beta\end{array}$ \\
\hline $\begin{array}{l}\text { Leygue et al. } \\
(1998)\end{array}$ & $\begin{array}{l}\text { Normal } \\
\text { (adjacent tissues) } \\
\text { Cancer }\end{array}$ & $\begin{array}{l}18 \\
18\end{array}$ & $\begin{array}{l}\text { Multiplex } \\
\text { RT-PCR }\end{array}$ & $\begin{array}{c}+ \\
++/+++\end{array}$ & $\uparrow$ & $\begin{array}{l}++ \\
+\end{array}$ & $\downarrow$ & $\begin{array}{l}\text { Increase in } \mathrm{ER} \alpha \text { and decrease in } \\
\mathrm{ER} \beta \text { during tumor progression }\end{array}$ \\
\hline $\begin{array}{l}\text { Gustafsson } \\
\& \text { Warner } \\
(2000)\end{array}$ & $\begin{array}{l}\text { Normal } \\
\text { BBD } \\
\text { Cancer }\end{array}$ & $\begin{array}{l}\text { Total of } \\
30 \\
\text { samples }\end{array}$ & $\begin{array}{l}\text { RT-PCR } \\
\text { Western } \\
\text { blot, IHC }\end{array}$ & & $\uparrow$ & & $\downarrow$ & $\begin{array}{l}\mathrm{ER} \beta \text { is the predominant form in } \\
\text { normal mammary gland }\end{array}$ \\
\hline
\end{tabular}

The number of + indicates the ER's relative expression. The arrows indicate a decrease $(\downarrow)$, an increase $(\uparrow)$ or no variations in expression $(\longleftrightarrow)$ between normal and cancer tissues. $\mathrm{SQ}=$ semiquantitative, Ov = overall trends, BBD = benign breast disease, $\mathrm{NP}-\mathrm{BBD}=$ non proliferative BBD, $\mathrm{P}-\mathrm{BBD}=$ proliferative BBD, $\mathrm{P}-\mathrm{BBDWA}=$ proliferative $\mathrm{BBD}$ with atypia, $\mathrm{BBT}=$ benign breast tumors, $\mathrm{CIS}=$ carcinoma in situ, HGPIN = high-grade prostatic intraepithelial neoplasia, ISH = in situ hybridization, $\mathrm{IHC}=$ immunohistochemistry, Met = metastatic, RT-PCR = reverse transcription polymerase chain reaction.

ER $\beta$ mRNA level was decreased in most of the tumor samples as compared with normal prostate, suggesting that $E R \alpha$ and $E R \beta$ expression status could be used to identify advanced prostate tumor patients. This result is in agreement with those obtained at the protein level. Pasquali et al. (2001a) investigated ER $\beta$ expression in benign and malignant prostate tissue specimens, using a polyclonal antibody directed against the C-terminal domain of the ER $\beta$ protein. In contrast to normal tissues, ER $\beta$ nuclear immunostaining was undetectable in all cancer sections, showing that malignancy seems to be associated with the disappearance of ER $\beta$ expression in prostate tissue. Horvath et al. (2001), using IHC, also found that the ER $\beta$ protein was progressively lost in hyperplasia and neoplastic lesions. This is in agreement with the results of Fixemer et al. (2003) in a study in which a new monoclonal antibody revealed the differential expression of ER $\beta$ in tissue sections from 132 patients with prostate cancer. Moreover, these authors showed partial loss of ER $\beta$ in high-grade prostatic intraepithelial neoplasia (HGPIN) (Table 3). Once more, the change in ER $\alpha$ / ER $\beta$ ratio seems to be correlated with malignancy.

In colon cancer, the protective effect of estrogen replacement therapy is supported by a number of clinical observations (Calle et al. 1995, Newcomb et al. 1995, Perssonet al. 1996, Kampman et al. 1997), including the results of recent randomized studies named 'WHI' (Nelson et al. 2002, Rossouw et al. 2002). These studies demonstrated that women with a history of current or past hormone replacement therapy had a significantly decreased risk of colon cancer. These findings have led many investigators to search for the biologic mechanisms 
Bardin et al.: ER $\beta$ and estrogen-dependent cancers

Table 2 Relative expression of $\mathrm{ER} \alpha$ and $\mathrm{ER} \beta$ in ovarian tumor progression

\begin{tabular}{|c|c|c|c|c|c|c|c|c|}
\hline \multirow{2}{*}{ References } & \multirow{2}{*}{ Tissues } & \multirow{2}{*}{ Number } & \multirow{2}{*}{ Methods } & \multirow{2}{*}{$\frac{\mathrm{ER} \alpha}{\mathrm{SQ} O \mathrm{v}}$} & & \multirow{2}{*}{$\frac{\mathrm{ER} \beta}{\mathrm{SQ} \mathrm{Ov}}$} & & \multirow{2}{*}{ Comments } \\
\hline & & & & & & & & \\
\hline $\begin{array}{l}\text { Pujol et al. } \\
\text { (1998) }\end{array}$ & $\begin{array}{l}\text { Normal } \\
\text { Cysts } \\
\text { Borderline tumors } \\
\text { Cancers }\end{array}$ & $\begin{array}{r}6 \\
24 \\
3 \\
10\end{array}$ & $\begin{array}{l}\text { Competitive } \\
\text { RT-PCR }\end{array}$ & $\begin{array}{l}+ \\
+ \\
++ \\
++\end{array}$ & $\uparrow$ & $\begin{array}{l}+++ \\
+++ \\
++ \\
+\end{array}$ & $\downarrow$ & $\begin{array}{l}\mathrm{ER} \alpha / \mathrm{ER} \beta \text { mRNA ratio } \\
\text { increases during tumor } \\
\text { progression }\end{array}$ \\
\hline $\begin{array}{l}\text { Brandenberger et al. } \\
\text { (1998) }\end{array}$ & $\begin{array}{l}\text { Normal } \\
\text { Cancer }\end{array}$ & $\begin{array}{l}10 \\
10\end{array}$ & $\begin{array}{l}\text { Northern } \\
\text { blot } \\
\text { RT-PCR }\end{array}$ & $\begin{array}{l}++ \\
+++\end{array}$ & $\uparrow$ & $\begin{array}{l}++ \\
+\end{array}$ & $\downarrow$ & $\begin{array}{l}\text { ER } \beta \text { mRNA level } \\
\text { decreases in cancer }\end{array}$ \\
\hline $\begin{array}{l}\text { Rutherford et al. } \\
(2000)\end{array}$ & $\begin{array}{l}\text { Normal } \\
\text { Primary cancer } \\
\text { Met. cancer }\end{array}$ & $\begin{array}{l}9 \\
8 \\
8\end{array}$ & $\begin{array}{l}\text { RT-PCR } \\
\text { Western } \\
\text { blot }\end{array}$ & $\begin{array}{l}++ \\
++ \\
+++\end{array}$ & $\uparrow$ & $\begin{array}{l}++ \\
+ \\
-\end{array}$ & $\downarrow \downarrow$ & $\begin{array}{l}\text { ER } \beta \text { mRNA and protein } \\
\text { levels decrease in ovarian } \\
\text { cancer and metastases }\end{array}$ \\
\hline
\end{tabular}

by which estrogen may influence the pathogenesis of colorectal cancer. Since $\mathrm{ER} \alpha$ is reported to be minimally expressed in normal colon mucosa and colon cancer cells (Waliszewski et al. 1997, Campbell-Thompson et al. 2001), the effects of estrogen on colon cancer susceptibility may be mediated by ER $\beta$. Using semiquantitative RT-PCR, Campbell-Thompson et al. (2001) showed that $\mathrm{ER} \beta$ is the predominant ER subtype in the human colon, and that decreased ER $\beta 1$ (ER $\beta w t)$ and ER $\beta 2$ (ER $\beta c x)$
mRNA levels are associated with colonic tumorigenesis in women. In a recent study using IHC analysis, Konstantinopoulos et al. (2003) showed that ER $\beta$ expression was significantly lower in colon cancer cells than in normal colonic epithelium, and that there was a progressive decline in ER $\beta$ expression, which paralleled the loss of malignant colon cell dedifferentiation. These findings are in accordance with a previous study of Foley et al. (2000), who also detected a selective loss of $\operatorname{ER} \beta$ protein in

Table 3 Relative expression of ER and ER $\beta$ in prostate tumor progression

\begin{tabular}{|c|c|c|c|c|c|c|c|c|}
\hline \multirow{2}{*}{ References } & \multirow{2}{*}{ Tissues } & \multirow{2}{*}{ Number } & \multirow{2}{*}{ Methods } & \multirow{2}{*}{$\begin{array}{l}\mathrm{ER} \alpha \\
\mathrm{SQ} \mathrm{Ov}\end{array}$} & & \multirow{2}{*}{$\begin{array}{l}\mathrm{ER} \beta \\
\mathrm{SQ} \mathrm{Ov}\end{array}$} & & \multirow{2}{*}{ Comments } \\
\hline & & & & & & & & \\
\hline $\begin{array}{l}\text { Latil et al. } \\
(2001)\end{array}$ & $\begin{array}{l}\text { Normal } \\
\text { Cancer }\end{array}$ & $\begin{array}{r}4 \\
23\end{array}$ & $\begin{array}{l}\text { Real-time } \\
\text { PCR }\end{array}$ & $\begin{array}{l}++ \\
+ \text { to }++\end{array}$ & $\leftrightarrow$ & $\begin{array}{l}+++ \\
+\end{array}$ & $\downarrow$ & $\begin{array}{l}\text { ER } \beta \text { mRNA expression decreases } \\
\text { in the hormone-resistant group }\end{array}$ \\
\hline $\begin{array}{l}\text { Pasquali et al. } \\
\text { (2001a) }\end{array}$ & $\begin{array}{l}\text { Normal } \\
\text { Cancer }\end{array}$ & $\begin{array}{r}5 \\
10\end{array}$ & $\mathrm{IHC}$ & / & & $\begin{array}{l}+++ \\
+\end{array}$ & $\downarrow$ & $\begin{array}{l}\text { ER } \beta \text { protein expression decreases } \\
\text { in cancer }\end{array}$ \\
\hline $\begin{array}{l}\text { Pasquali et al. } \\
(2001 b)\end{array}$ & $\begin{array}{l}\text { Normal } \\
\text { Cancer }\end{array}$ & $\begin{array}{l}6 \\
5\end{array}$ & $\begin{array}{l}\text { RT-PCR } \\
\text { Western } \\
\text { blot }\end{array}$ & $\begin{array}{l}++ \\
++\end{array}$ & $\leftrightarrow$ & $\begin{array}{l}++ \\
+\end{array}$ & $\downarrow$ & $\begin{array}{l}\text { ER } \beta \text { mRNA expression decreases } \\
\text { in cancer }\end{array}$ \\
\hline $\begin{array}{l}\text { Horvath et al. } \\
\text { (2001) }\end{array}$ & $\begin{array}{l}\text { Normal } \\
\text { Hyperplasia } \\
\text { Cancer }\end{array}$ & $\begin{array}{r}5 \\
157 \\
159\end{array}$ & $\mathrm{IHC}$ & I & & $\begin{array}{l}+++ \\
- \text { or }+ \\
- \text { or }+\end{array}$ & $\downarrow$ & $\begin{array}{l}\text { Loss of ER } \beta \text { protein expression } \\
\text { during tumor progression }\end{array}$ \\
\hline $\begin{array}{l}\text { Leav et al. } \\
(2001)\end{array}$ & $\begin{array}{l}\text { Dysplasia } \\
\text { - moderate grade } \\
\text { - high grade } \\
\text { Carcinoma } \\
\text { - grade III } \\
\text { - grade IV/V } \\
\text { Metastasis }\end{array}$ & $\begin{array}{l}\text { Total of } \\
50 \\
\text { samples }\end{array}$ & $\begin{array}{l}\text { IHC } \\
\text { RT-PCR }\end{array}$ & $\begin{array}{l}- \\
- \\
-1+ \\
-1+ \\
-\end{array}$ & $\leftrightarrow$ & $\begin{array}{l}+ \\
- \\
+ \\
-1+ \\
+\end{array}$ & $\leftrightarrow$ & $\begin{array}{l}\text { ER } \beta \text { protein and mRNA expression } \\
\text { decrease in high-grade dysplasia } \\
\text { and carcinoma }\end{array}$ \\
\hline $\begin{array}{l}\text { Fixemer et al. } \\
\text { (2003) }\end{array}$ & $\begin{array}{l}\text { HGPIN } \\
\text { Adenocarcinoma } \\
\text { Gleason grade: } \\
\text { III } \\
\text { IV } \\
\text { V } \\
\text { Metastatic }\end{array}$ & $\begin{array}{l}17 \\
29 \\
14 \\
12\end{array}$ & $\begin{array}{l}\text { IHC } \\
\text { Monoclonal } \\
\text { antibody }\end{array}$ & I & & $\begin{array}{l}+++ \\
+ \\
++ \\
+ \\
+\end{array}$ & $\downarrow$ & $\begin{array}{l}\text { ER } \beta \text { protein expression decreases } \\
\text { during tumor progression } \\
\text { ER } \beta \text { expression higher in Gleason } \\
\text { grade IV than in grades III and V }\end{array}$ \\
\hline
\end{tabular}


Table 4 Relative expression of ER $\alpha$ and $\mathrm{ER} \beta$ in colon tumor progression

\begin{tabular}{|c|c|c|c|c|c|c|c|c|}
\hline \multirow{2}{*}{ References } & \multirow{2}{*}{ Tissues } & \multirow{2}{*}{ Number } & \multirow{2}{*}{ Methods } & \multicolumn{2}{|l|}{$\mathrm{ER} \alpha$} & \multicolumn{2}{|l|}{ ER $\beta$} & \multirow{2}{*}{ Comments } \\
\hline & & & & SQ Ov & & SQ Ov & & \\
\hline \multirow{2}{*}{$\begin{array}{l}\text { Campbell-Thompson } \\
\text { et al. (2001) }\end{array}$} & Normal & 26 & RT-PCR & + & \multirow[t]{2}{*}{$\leftrightarrow$} & +++ & \multirow[t]{2}{*}{$\downarrow$} & \multirow{2}{*}{$\begin{array}{l}\text { ER } \beta 1 \text { and ER } \beta 2 \text { mRNA expressions } \\
\text { decrease in cancer }\end{array}$} \\
\hline & Cancer & 26 & $\begin{array}{l}\text { Southern } \\
\text { blot }\end{array}$ & + & & + & & \\
\hline \multirow{2}{*}{$\begin{array}{l}\text { Foley et al. } \\
(2000)\end{array}$} & Normal & 11 & RT-PCR & + & \multirow[t]{2}{*}{$\leftrightarrow$} & +++ & \multirow[t]{2}{*}{$\downarrow$} & \multirow{2}{*}{$\begin{array}{l}\text { Decrease ER } \beta \text { protein but not mRNA } \\
\text { expression in cancer } \\
\text { Post-transcriptional mechanism? }\end{array}$} \\
\hline & Cancer & 11 & $\begin{array}{l}\text { Western } \\
\text { blot }\end{array}$ & + & & + & & \\
\hline
\end{tabular}

malignant human colon by Western immunoblotting. Weyant et al. (2001) worked with a model of mice bearing germline mutations in murine Apc. These mice develop multiple intestinal tumors that show loss of wild-type Apc protein. In this model, E2-induced prevention of Apcassociated tumor formation was correlated with an increase in $\mathrm{ER} \beta$ protein and a decrease in $\mathrm{ER} \alpha$ in target tissues. Altogether, these results strongly suggest that ER $\beta$ protects against colon carcinogenesis (Table 4).

\section{ERß as a predictive factor for antiestrogen therapy?}

Although many reports suggest the protective role of $E R \beta$ against tumor progression, controversies have arisen regarding the clinical value of ER $\beta$ expression in terms of predicting the adjuvant hormonal therapy response in breast cancer. Some studies suggest that the ER $\beta$ status in $\mathrm{BC}$ is a predictor of the response to tamoxifen (Leygue et al. 1998, Jarvinen et al. 2000, Mann et al. 2001) whereas others suggest that ER $\beta$ is significantly upregulated in tamoxifen-resistant breast cells and could be involved in tamoxifen resistance (Speirs et al. 1999).

The type of analysis, patient selection criteria, the type of splicing variants detected in RNA analyses or the small number of patients analyzed to date could ultimately explain these controversial results. The first findings were obtained in studies involving RT-PCR-based techniques, but the quantification of gene expression at the mRNA level may not be directly linked qualitatively or quantitatively to the protein expression. There have been very few studies in which ERs were measured by Western immunoblotting or IHC because of the lack of reliable antibodies. Finally, the choice of statistical analysis and different parameters selected for analysis could also influence the results.

\section{ERß as a potential tumor-suppressor gene?}

The results of these different studies, showing a loss of ER $\beta$ expression in cancer as compared with normal cells, are in line with the hypothesis that the ER $\beta$ gene may act as a tumor suppressor (Iwao et al. 2000). This concept needs to be confirmed but could make sense in view of the location of ER $\beta$ on chromosome 14q (Enmark et al. 1997). A loss of $14 q$ has been detected by comparative genomic hybridization in some breast cancers (Burki et al. 2000, Loveday et al. 2000). Interestingly, in ovarian cancer, two potential tumor-suppressor gene loci have been mapped to 14q (Bandera et al. 1997). 14q deletions are also observed in colon carcinoma (Young et al. 1993) and prostate cancer (Kasahara et al. 2002). These overall findings suggest a potential tumor-suppressive function for ER $\beta$. However, further studies are required before definitive conclusions on the tumor-suppressive function of ER $\beta$ can be drawn.

\section{What are the potential molecular mechanisms underlying ER $\alpha$ and ER $\beta$ differential actions?}

Several in vitro studies have focused on the molecular mechanisms underlying the differential roles of $\mathrm{ER} \alpha$ and ER $\beta$. Differences in ligand affinity, transcriptional activation, interactions with cofactors or putative heterodimerisation have been proposed.

\section{Structural properties of ER $\alpha$ and ER $\beta$ and effects on their transcriptional activities}

$\mathrm{ER} \alpha$ and $\beta$ belong to the large nuclear steroid/thyroid hormone receptor family. Like most other members of the family, ERs have a modular architecture of four interacting domains: the N-terminal A/B domain, the C or DNAbinding domain (DBD), the $\mathrm{D}$ or hinge domain and the $\mathrm{C}$ terminal $\mathrm{E} / \mathrm{F}$ or ligand-binding domain (LBD) (Fig. 1). There is only $56 \%$ amino-acid identity between the two receptors in the $\mathrm{LBD}$, whereas the homology in the $\mathrm{DBD}$ is $97 \%$. This suggests that ER $\beta$ would recognize and bind to the same EREs as ER $\alpha$, but that each receptor might have a distinct spectrum of ligands (Kuiper \& Gustafsson 1997). A number of novel selective ER subtype ligands have now been developed. The propyl pyrazole triol (PPT) com- 


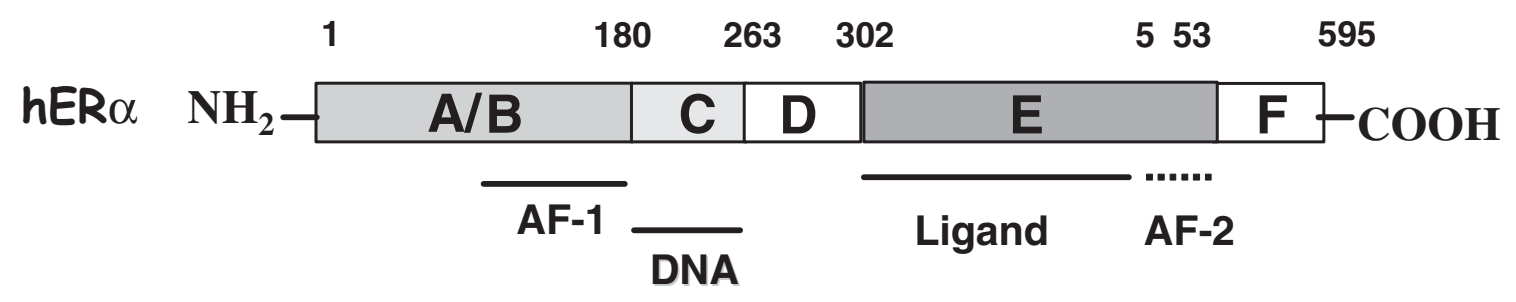

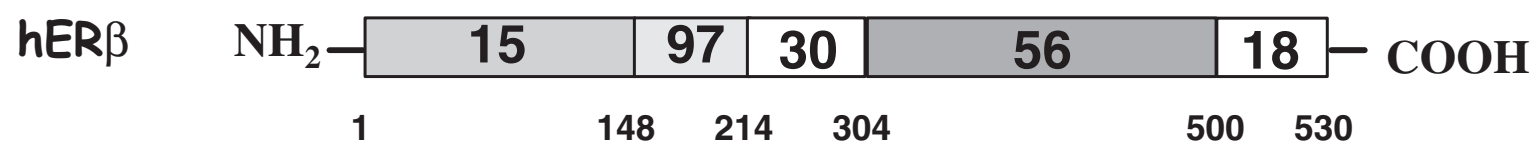

CDNA

ER gene

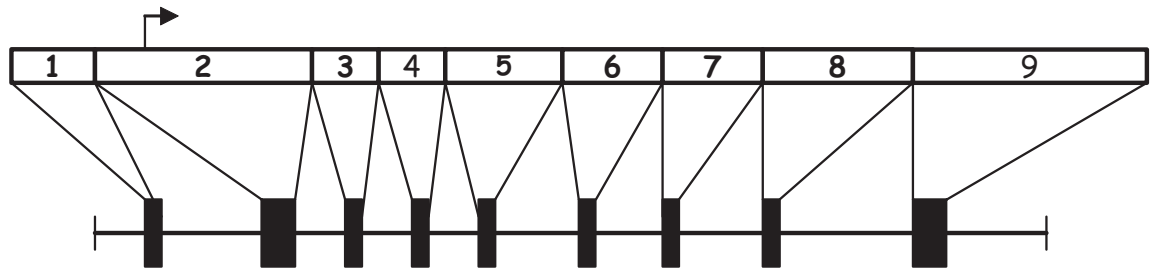

Figure 1 Schematic representation of the structure of human (h)ER $\alpha$ and $E R \beta$ nuclear receptors. The $A / B$ domain at the NH-2 terminal contains the ligand-independent transcriptional-activation function AF-1, the $C$ domain represents the DNA-binding-domain, the $\mathrm{D}$ domain corresponds to the hinge region, and the $\mathrm{E}$ domain contains the hormone-binding domain and the hormone-dependent transcriptional-activation function AF-2. Numbers outside each box refer to amino acid number, whereas the number inside each box of ER $\beta$ refers to the percentage of amino acid identity. The arrow indicates the translation starting site in ER cDNA.

pound was found to be an ER $\alpha$-specific agonist, activating gene transcription only through $\mathrm{ER} \alpha$ (Sun et al. 1999, Stauffer et al. 2000). A number of other known ligands are also somewhat ER $\beta$ selective. Some phytoestrogens, such as genistein and coumestrol, show a higher affinity toward ER $\beta$ than ER $\alpha$ (Kuiper \& Gustafsson 1997). The diarylpropionitrile (DPN) compound is a potency-selective agonist for ER $\beta$ with a more than 70-fold higher binding affinity for $\mathrm{ER} \beta$ than $\mathrm{ER} \alpha$ (Meyers et al. 2001). Recently, Ghosh et al. (2003) have investigated a novel series of heterocycle ligands for the ERs based on a diazene core motif. In this process, they have found diazenes that have high binding affinity for the ERs, and some of these show preferential affinity for $\mathrm{ER} \alpha$ or for $\mathrm{ER} \beta$.

The N-terminal domain of nuclear receptors encodes a ligand-independent activation function (AF-1) (Tora et al. 1989, Berry et al. 1990, McInerney \& Katzenellenbogen 1996), a region of the receptor involved in proteinprotein interactions (Onate et al. 1998), and transcriptional stimulation of target gene expression. The activation function-2 (AF-2) domain, located in the LBD (Tora et al. 1989), is responsible for hormonedependent activation through recruitment of coactivator proteins (Tremblay et al. 1997, White et al. 1997). There is very little conservation in the N-terminal AF-1 domain, a fact which could explain why different sets of proteins in the transcription complexes may interact with $E R \alpha$ and $E R \beta$ and direct them to specific targets. Dissimilarity in the $\mathrm{NH}_{2}$-terminal extremity of $\mathrm{ER} \alpha$ and $\mathrm{ER} \beta$ is one possible explanation for the difference in the response of the two receptors to various ligands. In fact, the two receptors are distinct in their responses to the synthetic antiestrogens tamoxifen, raloxifen and ICI164,384. On an ERE-based reporter gene assay, tamoxifen, 4-OH-tamoxifen, raloxifen and ICI-164,384 have an ER $\alpha$-selective partial agonist/antagonist function but pure ER antagonist effect through ER $\beta$ (McDonnell et al. 1995, Barkem et al. 1998, McInerney et al. 1998). Watanabe et al. (1997) showed that the agonistic effect of tamoxifen depends on the cell type, ERE-promoter context, and ER subtypes, and that this action is ER $\alpha$ specific. Tamoxifen is an ER $\alpha$ antagonist in breast (Jordan et al. 1992) but an agonist in bone (Love et al. 1992) and uterine tissues (Kedar et al. 1994). Raloxifene is also an ER $\alpha$ antagonist in breast tissue, but it exerts agonistic activity in bone, but not in uterine tissue (Black et al. 1994). 
$\mathrm{ER} \alpha$ and $\mathrm{ER} \beta$ are capable of regulating gene transcription through a classical mechanism involving the consensus ERE, but ER $\beta$ seems to be a weaker transactivator (Cowley et al. 1999). Cowley and Parker (1999) have shown that the AF-1 activity of ER $\beta$ is weak compared with that of $\mathrm{ER} \alpha$ on estrogen-responsive reporters, whereas their AF-2 activities are similar. In turn, when both AF-1 and AF-2 functions are active in a particular cell and/or on a particular promoter, the activity of $E R \alpha$ greatly exceeds that of $E R \beta$, whereas $\mathrm{ER} \alpha$ and $\mathrm{ER} \beta$ activities are similar when only AF-2 is required (McInerney et al. 1998, Cowley et al. 1999). ER $\alpha$ and $\operatorname{ER} \beta$ have similar but also different effects on gene transcription mediated via the ERE. To date, only a limited number of genes have been shown to be regulated by one of the two E2-liganded ER subtypes in this classical mode of action. In this way, the gene encoding the catalytic subunit of human telomerase hTERT is regulated by $E R \alpha$, and not by $E R \beta$ in human ovary epithelium cells (Misiti et al. 2000) and in human prostate cancer (Nanni et al. 2002). In the same way, Lazennec et al. (2001) reported that, $\mathrm{ER} \alpha$, but not $\operatorname{ER} \beta$, was able to regulate c-myc proto-oncogene expression. The metallothionein gene is known to be specifically upregulated by E2 via ER $\beta$ in SAOS-2 cells (Harris et al. 2001). However, recently, Stossi et al. (2004) have compared the generegulatory activities of $E R \alpha$ and $E R \beta$ in bone and showed high similarity but also significant differences in gene targets for these two ERs. Thus, genes encoding for cystatin D, autotaxin or stromal antigen 2 appear to be E2-regulated specifically by ER $\beta$ in human osteosarcoma cells.

Estrogens (and antiestrogens) also transcriptionally regulate target genes via ERs though a non-ERE mode of action. These effects are mediated through promoter elements that bind various transcription factors, including AP-1-binding sites (Webb et al. 1995), Sp1 binding sites (Porter et al. 1997), SF1 response element (SFRE) (Vanacker et al. 1999), electrophophilic/antioxidant response element (EpRE/ARE) (Montano et al. 1997) and cyclic AMP response element (CRE) (Sabbah et al. 1999). At AP-1 sites, ER $\alpha$ and ER $\beta$ could have opposite transcriptional effects in some circumstances (Paech et al. 1997). In fact, ER $\beta$ is able to potentiate an AP-1containing reporter in the presence of the antiestrogen tamoxifen, but not in the presence of estrogens in a tissuespecific manner. ER $\alpha$ stimulates AP-1 activity in the presence of antiestrogens in endometrial cells (Webb et al. 1995, Paech et al. 1997), but antiestrogens decrease or have no effect on AP-1 activity in BC cells (Philips et al. 1993, Webb et al. 1995). Of particular note, $\mathrm{ER} \beta$ is more potent overall than ER $\alpha$ on AP-1 sites, whereas the contrary occurs on EREs (Paech et al. 1997, Cowley et al.
1999, Hall et al. 1999). Similar to AP-1, E2 binding to $\mathrm{ER} \alpha$ induces transcriptional activation when associated with SP1 in GC-rich regions. However, E2 interaction with ER $\beta$ does not result in the formation of a transcriptionally active complex at a promoter containing Sp1 elements (Saville et al. 2000). Vanacker et al. (1999) found that the osteopontin gene promoter is stimulated through SFRE sequences by $\mathrm{ER} \alpha$, but not by ER $\beta$.

Consequently, these differences in ligand interaction or transcriptional activity between the two ER subtypes may account for the major differences in their tissuespecific biologic actions. This complexity is further enhanced by ER $\beta$ isoforms, the ability of ERs to form homodimers and heterodimers, and their capacity to interact with various coregulators.

\section{ER isoforms}

Several groups have reported and cloned different ER $\beta$ isoforms with exon deletions ( $\mathrm{Lu}$ et al. 1998), insertions (Hanstein et al. 1999), or C-terminal splice variants (Moore et al. 1998, Ogawa et al. 1998). These isoforms can also bind ligands, mediate estrogen signaling (Kuiper \& Gustafsson 1997, Paech et al. 1997, Cowley et al. 1999, Bollig et al. 2000) and exhibit different properties, thus further enhancing the complexity in the spectrum of potential cellular responses to estrogen. The key element lies perhaps in the balance between the expression of these different variants and their relative quantities. It has been shown that ER $\beta$ splice variants have dramatically different localization patterns in living cells, and this localization can be altered by estrogen agonists and antagonists (Price et al. 2001). Interestingly, Poola et al. (2002) recently showed that ER $\beta$ splice variant mRNAs were differentially altered during breast carcinogenensis. ER $\beta c x$, which utilizes an alternative exon 8 , is the most extensively studied splice variant. Ogawa et al. (1998) showed that this isoform may act as a potential inhibitor of $\mathrm{ER} \alpha$ transactivation, possibly due to $\mathrm{ER} \alpha / \mathrm{ER} \beta \mathrm{cx}$ heterodimer formation. Using IHC, it has been shown that differential expression of ER $\beta w t$ and ER $\beta c x$ may be used as a prognostic marker in human prostate (Fujimura et al. 2001). Peng et al. (2003) showed that all ER $\beta$ isoforms inhibited $\mathrm{ER} \alpha$ transcriptional activity on an ERE, while only ER $\beta w t$ had transcriptional activity of its own. It has been shown, using cDNA microarrays in MCF-7 cells stably transfected with ER $\beta w$ t and ER $\beta c x$ $\mathrm{MCF}-7$, that these two isoforms inhibit $\mathrm{ER} \alpha$ function differently (Omoto et al. 2003). Consequently, it can be hypothesized that the differential expression of ER $\beta$ isoforms may have a role in the modulation of estrogen action. 


\section{ER homo- and heterodimers}

The functional formation of $\mathrm{ER} \alpha$ and $\mathrm{ER} \beta$ heterodimers has been demonstrated (Cowley et al. 1997, Pettersson et al. 1997). They are able to bind to DNA with an affinity similar to that of $E R \alpha$ and greater than that of $E R \beta$ homodimers, to interact with coactivators, and to stimulate the transcription of reporter gene in transfected cells (Cowley et al. 1997, Pettersson et al. 1997). The possible involvement of $\mathrm{ER} \alpha$ and $\mathrm{ER} \beta$ dimerization would increase the complexity of transcription activation in response to E2, suggesting the existence of two previously unrecognized estrogen-signaling pathways, that is, $\mathrm{ER} \beta$ homodimers and $\mathrm{ER} \alpha / \mathrm{ER} \beta$ heterodimers. Moreover, it has been reported that various ER $\alpha$ and $\mathrm{ER} \beta$ ratios in different cells, resulting in different homodimer and heterodimer compositions, may constitute a key to gaining insight into the tissue-specific effects of estrogen and antiestrogens (Kuiper et al. 1997). Homodimers and heterodimers could bind to distinct response elements and consequently activate specific geneexpression patterns in given target tissues. For such interactions, ER $\alpha$ and ER $\beta$ must be coexpressed in cells, as noted in breast, ovarian and endometrium tissues. However, future studies will be required to determine the physiologic roles of $\mathrm{ER} \alpha$ and $\mathrm{ER} \beta$ homo- and heterodimers in vivo.

\section{Interactions with coactivators and corepressors}

There is one further confounding factor in the ERmediated estrogen action equation. The ER-mediated transcriptional activity of estrogen is influenced by several regulatory factors, known as coactivators and corepressors, which activate or repress the transcription of ERresponsive genes (Klinge et al. 2000). The p160/SRC (steroid receptor coactivator) family is one of the most studied classes of coactivators, and it includes SRC1, SRC2 (GRIP1/TIF-2) (McKenna et al. 1999) and other more recently described coactivators such as ACTR (Chen et al. 1997), RAC3 (Li et al. 1997), AIB1 (Anzick et al. 1997) and TRAM-1 (Takeshita et al. 1997). Most of interactions of these coregulators with the ER are liganddependent, but some coactivators have also been shown to be recruited in a ligand-independent manner by the AF-1 domain of ERs (McInerney et al. 1996, Tremblay et al. 1999). SRC-1 activated ER $\beta$ AF-1 upon MAPKinduced phosphorylation of serine residues (Tremblay et al. 1999). Deblois et al. (2003) studied the steroid receptor RNA activator (SRA) and showed that SRA potentiated the estrogen-induced transcriptional activity of both ER $\alpha$ and ER $\beta$. They demonstrated that the transcriptional activity of $E R \alpha$ can be enhanced by SRA in a ligand- independent manner through the AF-1 domain. However, this AF-1-dependent effect of SRA is not observed on ER $\beta$. Very few receptor-specific ER $\beta$ cofactors have been identified so far. Warnmark et al. (2001) showed that TRAP220 displays a preference for ER $\beta$ and suggested that the coregulator selectivity of ER subtypes is an additional layer of specificity that influences the transcriptional response in estrogen target cells. Using multiplex RT-PCR, Kurebayashi et al. (2000) also showed that ER $\beta$-expression levels were correlated with some activators such as AIB1, CBP, P/CAF, and a corepressor, N$\mathrm{CoR}$, but the significance of this correlation is unclear. Nuclear receptors usually bind the corepressors N-CoR and SMRT in the absence of ligand or in the presence of antagonists. Agonist binding leads to corepressor release and coactivator recruitment. Webb et al. (2003) recently demonstrated that, in vitro and in vivo, $\mathrm{ER} \beta$ binds to $\mathrm{N}$ CoR and SMRT in the presence of ER agonists, such as estradiol, and phytoestrogens, such as genistein, but not in the presence of antagonists. ER $\alpha$ and ER $\beta$ present completely distinct modes of action with coregulators, a fact which could be of major importance in terms of potential effects on physiologic behavior (Webb et al. 2003).

\section{What do we know about the role of ER $\beta$ in cell proliferation and death? \\ ER $\beta$ and cell proliferation}

Although the specific functions of ER $\beta$ in cancer are not known, there is some evidence that $\operatorname{ER} \beta$ could have inhibitory effects on cellular proliferation. First, as indicated previously, the levels of ER $\beta$ are highest in normal tissue (breast, ovary and prostate) as well as in benign disease, and they decrease during carcinogenesis (Tables 1-3). Our laboratory obtained the first evidence that ER $\beta$ is an important modulator of proliferation and invasion of breast and ovarian cancer cells, thus supporting the hypothesis that the loss of ER $\beta$ expression could be one of the events leading to breast and ovarian cancer development (Lazennec et al. 2001, Bardin et al. 2004). Whereas $\mathrm{ER} \alpha$ was able to regulate reporter genes and endogenous genes in a ligand-dependent manner, ER $\beta$ inhibited MDA-MB231 cell proliferation in a ligandindependent manner. This suggests that the two ERs inhibit cancer cell proliferation via different mechanisms (Lazennec et al. 2001).

Omoto et al. (2003) recently developed cell lines expressing ER $\beta w t$ and ER $\beta c x$ by stable transfection of each expression plasmid in MCF7 cells and demonstrated that this constitutive expression significantly reduced the percentage of cell population in S-phase and the number of colonies in an anchorage-independent assay. Recently, 


\section{Normal cells}
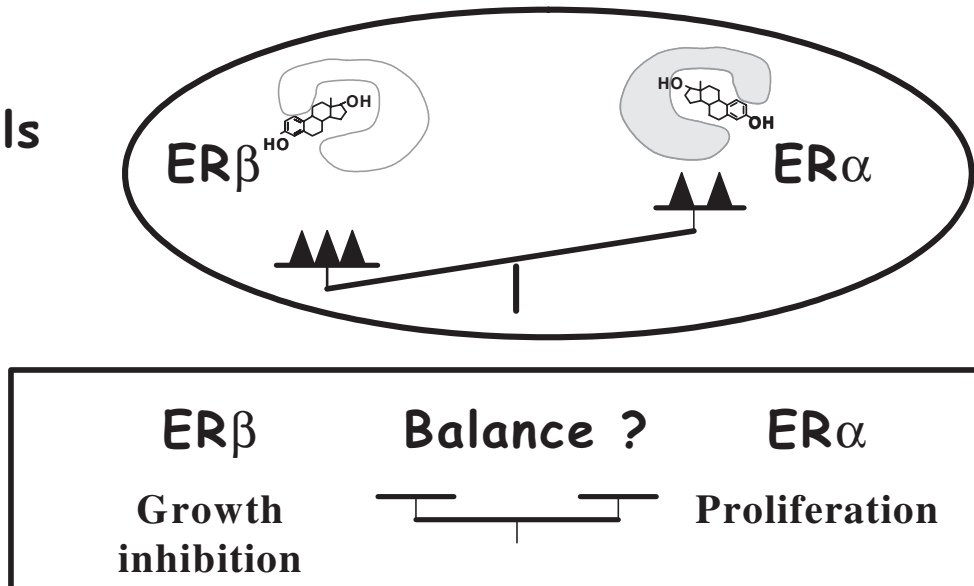

Tumor cells

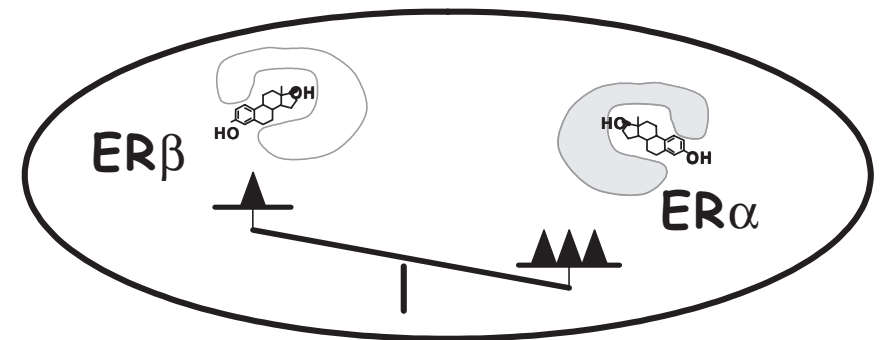

Figure 2 Schematic representation of $\operatorname{ER} \alpha$ and ER $\beta$ imbalance in estrogen-dependent tumor progression.

two studies showed that the induced expression of $\operatorname{ER} \beta$ in $\mathrm{ER} \alpha$-positive BC cells inhibits their growth (Paruthiyil et al. 2004, Strom et al. 2004). These reports also suggest that ER $\beta$ might reduce cell proliferation by inhibiting the cyclin D1 gene, a key factor controlling the G1-S transition of the cell cycle, and thus cell proliferation. Strom et al. (2004) also indicated that numerous other components of the cell cycle associated with proliferation, such as cyclin E or Cdc25A, were decreased. These results are in accordance with the study of Bièche et al. (2001), showing a negative correlation between ER $\beta$ and CCND1 (cyclin D1) expression. In vitro studies support the hypothesis of Liu et al. (2002), who showed that E2 activates cyclin D1 gene transcription through ER $\alpha$, but inhibits cyclin D1 gene transcription through ER $\beta$ in HeLa cells.

The contrasting phenotypes observed in individual lines of $\mathrm{ER}^{-/-}$mice, that is, $\mathrm{ER} \alpha \mathrm{KO}$ and $\mathrm{ER} \beta \mathrm{KO}$, which exhibit phenotypes that generally mirror the respective ER-expression patterns, provides further evidence that the two ERs have distinct biologic functions. Weihua et al. (2000) observed that, in the immature uterus, ER $\alpha$ and ER $\beta$ are expressed at comparable levels in the epithelium and stroma, and E2 treatment decreases ER $\beta$ in the stroma. Increased cell proliferation and the exaggerated response to $\mathrm{E} 2$ in $\mathrm{ER} \beta \mathrm{KO}$ mice suggests that $\mathrm{ER} \beta$ plays a role in the modulation of the effects of $E R \alpha$ and also (or consequently) has an antiproliferative function in the immature uterus. A second study in $E R \beta^{-/-}$mice showed that ER $\beta$ is implicated in the regulation of epithelial growth, and its absence results in hyperplasia of the prostatic epithelium (Weihua et al. 2001). The inhibition of $\mathrm{ER} \alpha$ transcriptional activity could be a molecular mechanism by which ER $\beta$ has antiproliferative effects. Previous in vitro data indicate that ER $\beta$ could act as a dominant negative regulator of $\mathrm{ER} \alpha$ activity. Hall et al. (1999) have provided direct proof that ER $\beta$ modulates or represses $E R \alpha$ transcriptional activity in transient transfection cells. In bone, it has been shown that ER $\beta$ inactivation by gene targeting results in increased cortical bone formation. Windalh et al. (2001) showed that, when present, ER $\beta$ acts in a repressive manner on trabecular bone, possibly by inhibiting the stimulatory action of $E R \alpha$. Finally, Lindberg et al. (2003) showed that in some mouse tissues, ER $\beta$ reduces $E R \alpha$-regulated gene transcription, thus indicating that there is a balanced relationship between $\operatorname{ER} \alpha$ and $\operatorname{ER} \beta$ (Fig. 2).

\section{ERß and apoptotic pathways?}

A decrease in the human cancer cell population in vitro or tumor regression in vivo reflects a change in the balance of cellular growth events and could involve arrested cell proliferation or an enhanced cell death, or both. 


\section{Hypothetical mechanism of antiproliferative effect of ER $\beta$}

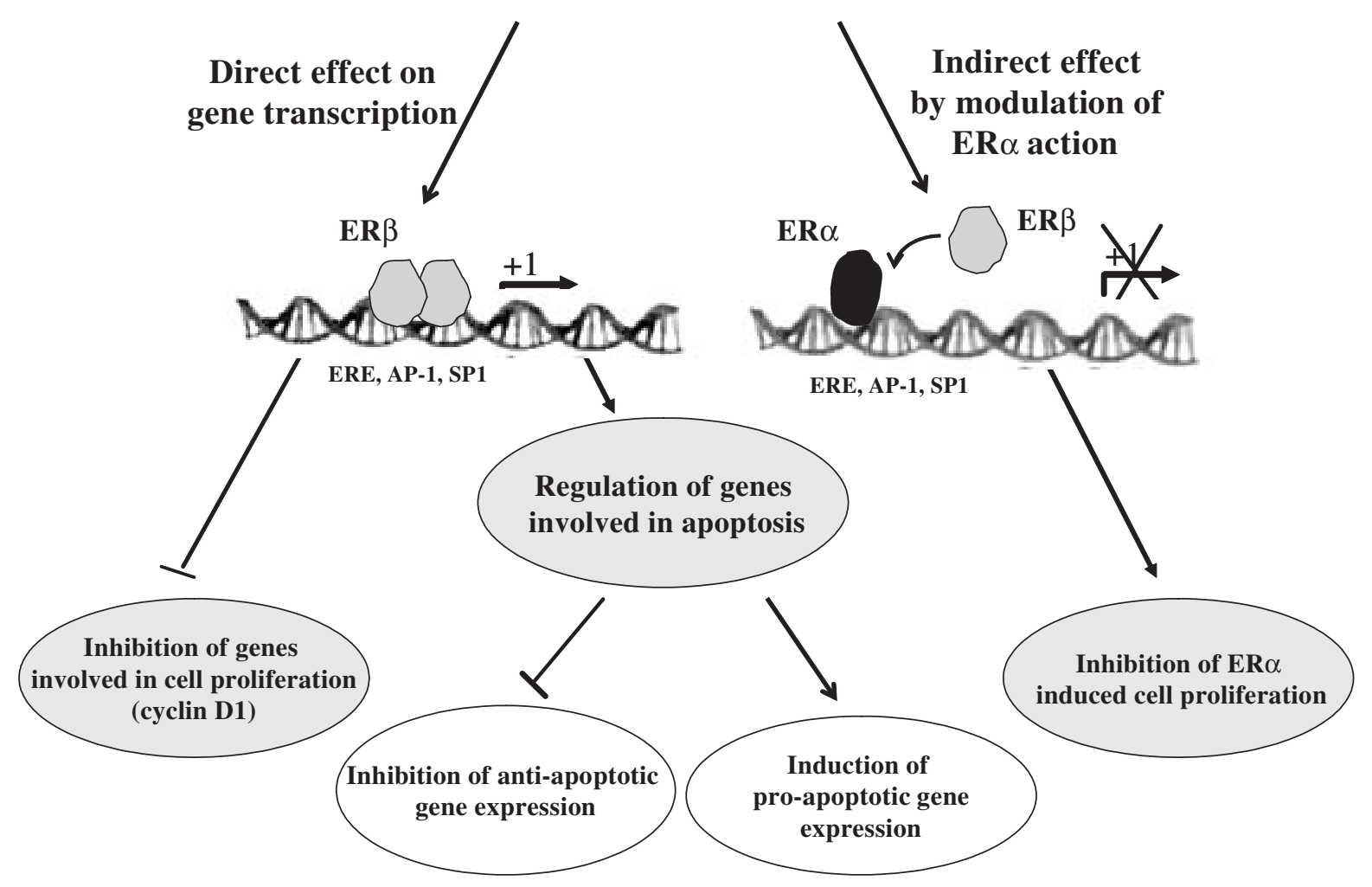

Figure 3 Hypothetical mode of ER $\beta$ action on cell proliferation pathways.

Several studies have suggested that estrogen may regulate apoptotic pathways in cancer (Kyprianou et al. 1991, Perillo et al. 2000, Choi et al. 2001). We could assume that E2 effects involve both proliferation induction and apoptosis inhibition. Choi et al. (2001) showed that E2 may be associated with upregulation of the antiapoptotic bcl-2 gene at the mRNA level. It has been suggested that $\mathrm{ER} \alpha$ may play a role in ovarian tumorigenesis by preventing apoptosis, whereas the ER $\beta$-induced inhibition of proliferation could be explained by the inhibition of the bcl-2 gene, as supported by a recent report of Nilsen et al. (2000). They showed that estradiol can function as a neuroprotective agent or an inducer of apoptosis, depending on the ER-subtype present in the cell. ER $\alpha$ is thus associated with a neuroprotective effect, while ER $\beta$ mediates the induction of apoptosis in neuronal cells. Similarly, Sapi et al. (2002) demonstrated estrogeninduced upregulation of FasL, an apoptotic protein ligand, in ovary. This may seem paradoxical since estrogen is known to be antiapoptotic in different cells. The authors proposed that in normal ovary the apoptotic protein ligand FasL is probably upregulated by ER $\beta$, the predominant form of ER in this tissue (Fig. 3). Recently, we have demonstrated (Cheng et al. in press) that the expression of ER $\beta$ in prostate carcinoma cells triggers apoptosis, notably by increasing bax $\alpha$ levels, as well as cleavage of PARP and caspase- 3 expression. We also observed pro-apoptotic effects of ER $\beta$ in ovarian cancer cells (Bardin et al. 2004).

\section{Conclusions}

Numerous clinical and in vitro studies suggest that imbalanced $E R \alpha / E R \beta$ expression is a common feature and could be a critical step of estrogen-dependent tumor progression. ER $\beta$ seems to play a key role in the mitogenic action of estrogen by providing protection against $\mathrm{ER} \alpha$-induced hyperproliferation. A role in apoptosis might also be possible.

$\mathrm{ER} \alpha$ and $\mathrm{ER} \beta$ have some overlapping tissue distribution but also display high relative tissue-specific expression. Moreover, a number of molecular mechanisms may explain the differential roles of $\operatorname{ER} \alpha$ and $\operatorname{ER} \beta$, including differences in ligand affinity and transactivation, distinct 
cofactor interactions and putative heterodimerization. Splicing variant ERs isoforms may also be important in modulating the cellular response.

In conclusion, the imbalance in $\mathrm{ER} \alpha / \mathrm{ER} \beta$ expression in estrogen-dependent cancer opens a new field in hormone therapy of cancer. Targeted ER $\beta$ therapies, including the development of ER $\beta$ specific ligands, may constitute a new therapeutic approach, particularly for pre-invasive or proliferative lesions. The clinical value of ER $\beta$ in cancer prognosis and its possible usefulness for prediction of the hormone response should be assessed in large-scale and prospective clinical studies.

\section{Acknowledgements}

This work was supported by the Ligue Nationale Contre le Cancer, the Centre Hospitalier Universitaire de Montpellier (grant no. AOI7619), the Association pour la Recherche contre le Cancer (grant no. 4302) and the Institut National de la Santé et de la Recherche Médicale.

\section{References}

Anderson GL, Judd HL, Kaunitz AM, Barad DH, Beresford SA, Pettinger M, Liu J, McNeeley SG \& Lopez AM - Women's Health Institute Investigators 2003 Effects of estrogen plus progestin on gynecologic cancers and associated diagnostic procedures: the Women's Health Initiative Randomized Trial. Journal of the American Medical Association 290 1739-1748.

Anzick SL, Kononen J, Walker RL, Azorsa DO, Tanner MM, Guan XY, Sauter G, Kallioniemi OP, Trent JM \& Meltzer PS 1997 AIB1, a steroid receptor coactivator amplified in breast and ovarian cancer. Science 277 965-968.

Bandera CA, Takahashi H, Behbakht K, Liu PC, LiVolsi VA, Benjamin I, Morgan MA, King SA, Rubin SC \& Boyd J 1997 Deletion mapping of two potential chromosome 14 tumor suppressor gene loci in ovarian carcinoma. Cancer Research $57513-515$.

Bardin A, Hoffmann P, Boulle N, Katsaros D, Vignon F, Pujol P \& Lazennec G 2004 Involvement of estrogen receptor $\beta$ in ovarian carcinogenesis. Cancer Research (In Press).

Barkhem T, Carlsson B, Nilsson Y, Enmark E, Gustafsson J \& Nilsson S 1998 Differential response of estrogen receptor alpha and estrogen receptor beta to partial estrogen agonists/ antagonists. Molecular Pharmacology 54 105-112.

Beral V \& Million Women Study Collaborators 2003 Breast cancer and hormone-replacement therapy in the Million Women Study. Lancet 362 419-427.

Berry M, Metzger D \& Chambon P 1990 Role of the two activating domains of oestrogen receptors in the cell-type and promoter-context dependent agonistic activity of the antioestrogen 4-hydroxytamoxifen. EMBO Journal 9 2811-2818.

Bièche I, Parfait B, Laurendeau I, Girault I, Vidaud M \& Lidereau R 2001 Quantification of estrogen receptor alpha and beta expression in sporadic breast cancer. Oncogene $\mathbf{2 0}$ 8109-8115.
Black LJ, Sato M, Rowley ER, Magee DE, Bekele A, Williams DC, Cullinan GJ, Bendele R, Kauffman RF, Bensch WR, et al. 1994 Raloxifene (LY139481 HCI) prevents bone loss and reduces serum cholesterol without causing uterine hypertrophy in ovariectomized rats. Journal of Clinical Investigation 93 63-69.

Bollig A \& Miksicek JR 2000 An estrogen receptor-alpha splicing variant mediates both positive and negative effects on gene transcription. Molecular Endocrinology 14 634-649.

Brandenberger AW, Tee MK \& Jaffe RB 1998 Estrogen receptor alpha (ER-alpha) and beta (ER-beta) mRNAs in normal ovary, ovarian serous cystadenocarcinoma and ovarian cancer cell lines: down-regulation of ER-beta in neoplastic tissues. Journal of Clinical Endocrinology and Metabolism $\mathbf{8 3}$ 1025-1028.

Burki NG, Caduff R, Walt H, Moll C, Pejovic T, Haller U \& Ward DC 2000 Comparative genomic hybridisation of fine needle aspirates from breast carcinomas. International Journal of Cancer 15 607-613.

Byers M, Kuiper GJ, Gustafsson JA \& Park-Sarge OK 1997 Estrogen receptor- $\beta$ mRNA expression in rat ovary: downregulation by gonadotropins. Molecular Endocrinology 11 172-182.

Calle EE, Miracle-Mahill HL, Thun MJ \& Health CW Jr 1995 Estrogen replacement therapy and risk of fatal colon cancer in a prospective cohort of postmenopausal women. Journal of the National Cancer Institute 87 517-523.

Campbell-Thompson M, Lynch J \& Bhardwaj B 2001 Expression of estrogen receptor (ER) subtypes ER beta isoforms in colon cancer. Cancer Research 61 632-640.

Chen H, Lin RJ, Schiltz RL, Chakravarti D, Nash A, Nagy L, Privalsky ML, Nakatani Y \& Evans RM 1997 Nuclear receptor coactivator ACTR is a novel histone acetyltransferase and forms a multimeric activation complex with $\mathrm{P} / \mathrm{CAF}$ and $\mathrm{CBP} / \mathrm{p} 300$. Cell 90 569-580.

Cheng J, Lee EJ, Madison LD \& Lazennec G 2004 Expression of estrogen receptor beta in prostate carcinoma cells inhibits invasion and proliferation and triggers apoptosis. FEBS Letters 566 169-172.

Chlebowski RT, Hendrix SL, Langer RD, Stefanick ML, Gass M, Lane D, Rodabough RJ, Gilligan MA, Cyr MG, Thomson CA, Khandekar J, Petrovitch \& McTiernan WHI Investigators 2003 Influence of estrogens plus progestin on breast cancer and mammography in healthy postmenopausal women: the Women's Health Initiative Randomized Trial. Journal of the American Medical Association 289 3243-3253.

Choi KC, Kang SK, Tai CJ, Auersperg N \& Leung PC 2001 Estradiol up-regulates antiapoptotic Bcl-2 messenger ribonucleic acid and protein in tumorigenic ovarian surface epithelium cells. Endocrinology 142 2351-2360.

Coughlin SS, Giustozzi A, Smith SJ \& Lee NC 2000 A metaanalysis of estrogen replacement therapy and risk of epithelial ovarian cancer. Journal of Clinical Epidemiology 53 367-375.

Cowley SM \& Parker MG 1999 A comparison of transcriptional activation by RE $\alpha$ and RE $\beta$. Journal of Steroid Biochemistry and Molecular Biology 69 165-175. 
Cowley SM, Hoare S, Mosselman S \& Parker MG 1997 Estrogen receptors $\alpha$ and $\beta$ form heterodimers on DNA. Journal of Biological Chemistry 272 19858-19862.

Deblois G \& Giguère V 2003 Ligand-independent coactivation of $\mathrm{ER} \alpha \mathrm{AF}-1$ by steroid receptor RNA activator (SRA) via MAPK activation. Journal of Steroid Biochemistry and Molecular Biology 85 123-131.

Enmark E, Pelto-Huikko M, Grandien K, Lagercrantz S, Lagercrantz J, Fried G, Nordenskjdd M \& Gustafsson JA 1997 Human estrogen receptor $\beta$ - gene structure, chromosome localization, expression pattern. Journal of Clinical Endocrinology and Metabolism 82 4258-4265.

Farnsworth WE 1999 Estrogen in the etiopathogenesis of BPH. Prostate 41 263-274.

Fixemer T, Remberger K \& Bonkhoff H 2003 Differential expression of the estrogen receptor beta in human prostate tissue, premalignant changes, and in primary, metastatic, and recurrent prostatic adenocarcinoma. Prostate 54 79-87.

Foley EF, Jazaeri AA, Shupnik MA, Jazaeri O \& Rice LW 2000 Selective loss of estrogen receptor beta in malignant human colon. Cancer Research 60 245-248.

Folsom AR, Anderson JP \& Ross JA 2004 Estrogen replacement therapy and ovarian cancer. Epidemiology 15 100-104.

Fujimura T, Takahashi S, Urano T, Ogawa S, Ouchi Y, Kitamura T, Muramatsu M \& Inoue S 2001 Differential expression of estrogen receptor $\beta$ (ER $\beta)$ and its $C$-terminal truncated splice variant ER $\beta \mathrm{cx}$ as prognostic predictors in human prostatic cancer. Biochemical and Biophysical Research Communications 289 692-699.

Fuqua SA, Shiff R, Parra I, Moore JT, Moshin SK, Osborne CK, Clark GM \& Allred C 2003 Estrogen receptor $\beta$ protein in human breast cancer: correlation with clinical tumor parameters. Cancer Research 63 2434-2439.

Ghosh U, Ganessunker D, Sattigeri VJ, Carlson KE, Mortensen DJ, Katzenellenbogen BS \& Katzenellenbogen JA 2003 Estrogenic diazenes: heterocyclic non-steroidal estrogens of unusual structure with selectivity for estrogen receptor subtypes. Bioorganic and Medicinal Chemistry 11 629-657.

Green S, Walter P, Kumar V, Krust A, Bornert JM, Argos P \& Chambon P 1986 Human estrogen receptor cDNA: sequence, expression and homology to v-erbA. Nature 320 134-139.

Gustafsson JA \& Warner M 2000 Estrogen receptor $\beta$ in the breast: role in estrogen responsiveness and development of breast cancer. Journal of Steroid Biochemistry and Molecular Biology 74 245-248.

Hall JM \& McDonnell DP 1999 The estrogen receptor $\beta$-isoform $(\mathrm{ER} \beta)$ of the human estrogen receptor modulates $\mathrm{ER} \alpha$ transcriptional activity and is a key regulator of the cellular response to estrogens and antiestrogens. Endocrinology 140 5566-5578.

Hanstein B, Liu H, Yancisin MC \& Brown M 1999 Functional analysis of a novel estrogen receptor- $\beta$ isoform. Molecular Endocrinology 13 129-137.

Harris HA, Henderson RA, Bhat RA \& Komm BS 2001 Regulation of metallothionein II messenger ribonucleic acid measures exogenous estrogen receptor- $\beta$ activity in SAOS-2 and LNCaPLN3 cells. Endocrinology 142 645-652.
Henderson BE, Ross R \& Bernstein L 1988 Estrogens as a cause of human cancer. Richard and Linda Rosenthal Foundation award lecture. Cancer Research 48 246-253.

Horvath LG, Henshall SM, Lee CS, Head DR, Quinn DI, Makela S, Delprado W, Golovsky D, Brenner PC, O'Neill G, Kooner R, Stricker PD, Grygiel JJ, Gustafsson JA \& Sutherland RL 2001 Frequent loss of estrogen receptor-beta expression in prostate cancer. Cancer Research 61 5331-5335.

Iwao K, Miyoshi Y, Egawa C, Ikeda N \& Noguchi S 2000 Quantitative analysis of estrogen receptor- $\beta$ mRNA and its variants in human breast cancers. International Journal of Cancer 88 733-736.

Jarred RA, Cancilla B, Prins GL, Thayer KA, Cunha GR \& Risbridger GP 2000 Evidence that estrogens directly alter androgen-regulated prostate development. Endocrinology 141 3471-3477.

Jarvinen TA, Pelto-Huikko M, Holli K \& Isola J 2000 Estrogen receptor beta is coexpressed with ER alpha and PR and associated with nodal status, grade, and proliferation rate in breast cancer. American Journal of Pathology 156 29-35.

Jordan VC 1992 The role of tamoxifen in the treatment and prevention of breast cancer. Current Problems in Cancer 16 129-176.

Kampman E, Potter JD, Slattery ML, Caan BJ \& Edwards S 1997 Hormone replacement therapy, reproductive history, and colon cancer: a multi-center, case-control study in the United States. Cancer Causes and Control 8 146-158.

Kasahara K, Taguchi T, Yamasaki I, Kamada M, Yuri K \& Shuin T 2002 Detection of genetic alterations in advanced prostate cancer by comparative genomic hybridisation. Cancer Genetics and Cytogenetics 137 59-63.

Kedar RP, Bourne TH, Powles TJ, Collins WP, Ashley SE, Cosgrove DO \& Campbell S 1994 Effects of tamoxifen on uterus and ovaries of postmenopausal women in a randomised breast cancer prevention trial. Lancet 343 1318-1321.

Klinge CM 2000 Estrogen receptor interaction with co-activators and co-repressors. Steroids 65 227-251.

Konstantinopoulos PA, Kominea A, Vandoros G, Sykiotis GP, Andricopoulos P, Varakis I, Sotiropoulou-Bonikou G \& Papavassiliou AG 2003 Estrogen receptor beta $(\mathrm{ER} \beta)$ is abundantly expressed in normal colonic mucosa, but declines in colon adenocarcinoma paralleling the tumor's dedifferentiation. European Journal of Cancer 39 1251-1258.

Kuiper G, Enmark E, Pelto-Huikko M, Nilsson S \& Gustafsson JA 1996 Cloning of a novel estrogen receptor expressed in rat prostate and ovary. PNAS 93 5925-5930.

Kuiper G, Carlsson B, Grandien K, Enmark E, MS Nilsson \& Gustafsson JA 1997a Comparison of the ligand binding specificity and transcript tissue distribution of estrogen receptor $\alpha$ and $\beta$. Endocrinology 138 863-870.

Kuiper G \& Gustafsson JA 1997b The novel estrogen receptorbeta subtype: potential role in the cell- and promoter-specific actions of estrogens and antiestrogens. FEBS Letters $\mathbf{4 1 0}$ 87-90.

Kurebayashi J, Sonoo H, Inaji H, Nishimura R, Iino Y, Toi M, Kobayashi S \& Saeki T 2000 Endocrine therapies for patients with recurrent breast cancer: predictive factors for responses 
to first- and second-line endocrine therapies. Oncology $\mathbf{5 9}$ 31-37.

Kyprianou N, English HF, Davidson NE \& Isaacs JT 1991 Programmed cell death during regression of the MCF-7 human breast cancer following estrogen ablation. Cancer Research 51 162-166.

Lacey JV Jr, Mink PJ, Lubin JH, Sherman ME, Troisi R, Hartge P, Schatzkin A \& Schairer C 2002 Menopausal hormone replacement therapy and risk of ovarian cancer. Journal of the American Medical Association 288 334-341.

Latil A, Bièche I, Vidaud D, Liderau R, Berthon P, Cussenot O \& Vidaud M 2001 Evaluation of androgen, estrogen (ER $\alpha$ and $\mathrm{ER} \beta$ ), and progesterone receptor expression in human prostate cancer by real-time quantitative reverse transcription-polymerase chain reaction assays. Cancer Research 61 1919-1926.

Lau KM, Mok SC \& Ho SM 1999 Expression of human estrogen receptor-alpha and -beta, progesterone receptor, and androgen receptor mRNA in normal and malignant ovarian epithelial cells. PNAS 96 5722-5727.

Lazennec G, Bresson D, Lucas A, Chauveau C \& Vignon F 2001 $E R \beta$ inhibits proliferation and invasion of breast cancer cells. Endocrinology 142 4120-4130.

Leav I, Lau KM, Adams JY, McNeal JE, Taplin ME, Wang J, Singh H \& Ho SM 2001 Comparative studies of the estrogen receptors beta and alpha and the androgen receptor in normal human prostate glands, dysplasia, and in primary and metastatic carcinoma. American Journal of Pathology 159 13-16.

Leygue EH, Dotzlaw H, Watson PH \& Murphy LC 1998 Altered estrogen receptor alpha and beta messenger RNA expression during human breast tumorigenesis. Cancer Research $\mathbf{5 8}$ 3197-3201.

Li H, Gomes PJ \& Chen JD 1997 RAC3, a steroid/nuclear receptor-associated coactivator that is related to SRC-1 and TIF2. PNAS 94 8479-8484.

Lindberg MK, Moverare S, Skrtic S, Gao H, Dahlman-Wright K, Gustafsson JA \& Ohlsson C 2003 Estrogen receptor (ER)beta reduces ERalpha-regulated gene transcription, supporting a 'ying yang' relationship between ERalpha and ERbeta in mice. Molecular Endocrinology 17 203-208.

Liu MM, Albanese C, Anderson CM, Hilty K, Webb P, Uht RM, Price RH Jr, Prestell RG \& Kushner PJ 2002 Opposing action of estrogen receptors alpha and beta on cyclin D1 gene expression. Journal of Biological Chemistry 277 24353-24360.

Love RR, Mazess RB, Barden HS, Epstein S, Newcomb PA, Jordan VC, Carbone PP \& DeMets DL 1992 Effects of tamoxifen on bone mineral density in postmenopausal women with breast cancer. New England Journal of Medicine 326 852-856

Loveday RL, Greenman J, Simcox DL, Speirs V, Drew PJ, Monson JR \& Kerin MJ 2000 Genetic changes in breast cancer detected by comparative genomic hybridisation. International Journal of Cancer 15 494-500.

Lu B, Leygue E, Dotzlaw H, Murphy LJ, Murphy LC \& Watson PH 1998 Estrogen receptor-beta mRNA variants in human and murine tissues. Molecular Cell Endocrinology 138 199-203.
Mann S, Laucirica R, Carlson N, Younes PS, Ali N, Younes A, Li Y \& Younes M 2001 Estrogen receptor beta expression in invasive breast cancer. Human Pathology 32 113-118.

McDonnell DP, Clemm DL, Hermann T, Goldman ME \& Pike JW 1995 Analysis of estrogen receptor function in vitro reveals three distinct classes of antiestrogens. Molecular Endocrinology 9 659-669.

McInerney EM \& Katzenellenbogen BS 1996 Different regions in activation function-1 of the human estrogen receptor required for antiestrogen- and estradiol-dependent transcription activation. Journal of Biological Chemistry 271 24172-24178.

McInerney EM, Tsai MJ, O'Malley BW \& Katzenellenbogen BS 1996 Analysis of estrogen receptor transcriptional enhancement by a nuclear hormone receptor coactivator. PNAS 93 10069-10073.

McInerney EM, Weis KE, Sun J, Mosselman S \& Katzenellenbogen BS 1998 Transcription activation by the human estrogen receptor subtype $\beta$ (ER $\beta$ ) studied with ER $\beta$ and $\mathrm{ER} \alpha$ receptor chimeras. Endocrinology 139 4513-4521.

McKenna NJ, Lanz RB \& O’Malley BW 1999 Nuclear receptor coregulators: cellular and molecular biology. Endocrine Reviews 20 321-344.

Meyers MJ, Sun J, Carlson KE, Maririner GA, Katzenellenbogen BS \& Katzenellenbogen JA 2001 Estrogen receptor- $\beta$ potency selective ligands: structure-activity relationship studies of diarylpropionitriles and their acetylene and polar analogues. Journal of Medicine and Chemistry $\mathbf{4 4}$ 4230-4251.

Misiti S, Nanni S, Fontemaggi G, Cong YS, Wen J, Hirte HW, Piaggio G, Sacchi A, Pontecorvi A, Bachetti S \& Farsetti A 2000 Induction of hTERT expression and telomerase activity by estrogens in human ovary epithelium cells. Molecular and Cellular Biology 20 3764-3771.

Montano MM \& Katzenellenbogen BS 1997 The quinone reductase gene: a unique estrogen-regulated gene that is activated by antiestrogens. PNAS 94 2581-2586.

Moore JT, McKee DD, Slentz-Kesler K, Moore LB, Jones SA, Home EL, Su JL, Kliewer SA, Lehmann JM \& Willson TM 1998 Cloning and characterization of human estrogen receptor beta isoforms. Biochemical and Biophysical Research Communications 9 75-78.

Mosselman S, Polman J \& Dijkema R 1996 RE-beta identification and characterization of a novel human estrogen receptor. FEBS Letters 392 49-53.

Nanni S, Narducci M, Della Pietra L, Moretti F, Grasseli A, De Carli P, Sacchi A, Pontecorvi A \& Farsetti A 2002 Signaling through estrogen receptors modulates telomerase activity in human prostate cancer. Journal of Clinical Investigation 110 219-227.

Nelson HD, Humphrey LL, Nygren P, Teutsch SM \& Allan JD 2002 Postmenopausal hormone replacement therapy: scientific review. Journal of the American Medical Association 288 872-881.

Newcomb PA \& Storer BE 1995 Postmenopausal hormone use and risk of large-bowel cancer. Journal of the National Cancer Institute 87 1067-1071.

Nilsen J, Mor G \& Naftolin F 2000 Estrogen-regulated developmental neuronal apoptosis is determined by estrogen 
receptor subtype and the Fas/Fas ligand system. Journal of Neurobiology 43 64-78.

Ogawa S, Inoue S, Watanabe T, Orimo A, Hosoi T, Ouchi Y \& Muramatsu M 1998 Molecular cloning and characterization of human estrogen receptor $\beta c x$ : a potential inhibitor of estrogen action in human. Nucleic Acids Research 26 3505-3512.

Omoto Y, Inoue S, Ogawa S, Toyama T, Yamashita H, Muramatsu M, Kobayashi S \& Iwase H 2001 Clinical value of the wild-type estrogen receptor $\beta$ expression in breast cancer. Cancer Letters 163 207-212.

Omoto Y, Eguchi H, Yamamoto-Yamaguchi Y \& Hayashi S 2003 Estrogen receptor (ER) $\beta 1$ and ER $\beta \mathrm{cx} / \beta 2$ inhibit $\mathrm{ER} \alpha$ function differently in breast cancer cell line MCF7. Oncogene 22 5011-5020.

Onate SA, Boonyaratanakornkit V, Spencer TE, Tsai SY, Tsai MJ, Edwards DP \& O'Malley BW 1998 The steroid receptor coactivator-1 contains multiple receptor interacting and activation domains that cooperatively enhance the activation function 1 (AF-1) and AF-2 domains of steroid receptors. Journal of Biological Chemistry 15 12101-12108.

Paech K, Webb P, Kuiper G, Nilsson S, Gustafsson JA, Kushner PJ \& Scalan TS 1997 Differential ligand activation of estrogen receptors RE $\alpha$ and RE $\beta$ at AP-1 sites. Science 277 1508-1510.

Park BW, Kim KS, Heo MK, KO SS, Hong SW, Yang WI, Kim JH, Kim GE \& Lee KS 2003 Expression of estrogen receptor$\beta$ in normal mammry and tumor tissues: is it protective in breast carcinogenesis? Breast Cancer Research and Treatment 80 79-85.

Paruthiyil S, Parmar H, Kerekatte V, Cunha GR, Firestone GL \& Leitman DC 2004 Estrogen receptor beta inhibits human breast cancer cell proliferation and tumor formation by causing a G2 cell cycle arrest. Cancer Research 64 423-428.

Pasquali D, Staibano S, Prezioso D, Franco R, Esposito D, Notaro A, De Rosa G, Bellastella A \& Sinisi AA 2001a Estrogen receptor $\beta$ expression in human prostate tissue. Molecular and Cellular Endocrinology 178 47-50.

Pasquali D, Rossi V, Esposito D, Abbondanza C, Puca GA, Bellastella A \& Sinisi AA $2001 b$ Loss of estrogen receptor $\beta$ expression in malignant human prostate cells in primary cultures and in prostate cancer tissues. Journal of Clinical Endocrinology and Metabolism 86 2051-2055.

Peng B, Lu B, Leygue E \& Murphy LC 2003 Putative functional characteristics of human estrogen receptor-beta isoforms. Journal of Molecular Endocrinology 30 13-29.

Perillo B, Sasso A, Abbondanza C \& Palumbo G 2000 17ßEstradiol inhibits apoptosis in MCF-7 cells, inducing bcl-2 expression via two estrogen-responsive elements present in the coding sequence. Molecular and Cellular Biology 20 2890-2901.

Persson I, Yuen J, Bergkvist L \& Schairer C 1996 Cancer incidence and mortality in women receiving estrogen and estrogen-progestin replacement therapy: long term follow-up of a Swedish cohort. International Journal of Cancer $\mathbf{6 7}$ 327-332.

Pettersson K, Grandien K, Kuiper G \& Gustafsson JA 1997 Mouse estrogen receptor beta forms estrogen response element-binding heterodimers with estrogen receptor alpha. Molecular Endocrinology 11 1486-1496.
Philips A, Chalbos D \& Rochefort H 1993 Estradiol increases and antiestrogens antagonize the growth factor-induced activator protein-1 activity in MCF7 breast cancer cells without affecting c-fos and c-jun synthesis. Journal of Biological Chemistry 268 14103-14108.

Pike MC, Spicer DV, Dahmoush L \& Press MF 1993 Estrogens, progestagens, normal breast cancer proliferation, and breast cancer risk. Epidemiology Reviews 15 17-35.

Poola I, Abraham J \& Liu A 2002 Estrogen receptor beta splice variant mRNAs are differentially altered during breast carcinogenesis. Journal of Steroid Biochemistry and Molecular Biology 82 169-179.

Porter W, Saville B, Hoivik D \& Safe S 1997 Functional synergy between the transcription factor Sp1 and the estrogen receptor. Molecular Endocrinology 11 1569-1580.

Price RH, Butler CA, Webb P, Uht R, Kushner P \& Handa RJ 2001 A splice variant of estrogen receptor $\beta$ missing exon 3 displays altered subnuclear localization and capacity for transcriptional activation. Endocrinology 142 2039-2049.

Pujol P, Rey JM, Nirde P, Roger P, Gastaldi M, Laffargues F, Rochefort H \& Maudelonde T 1998 Differential expression of estrogen receptor-alpha and -beta messenger RNAs as a potential marker of ovarian carcinogenesis. Cancer Research 58 5367-5373.

Rodriguez C, Patel AV, Calle EE, Jacob EJ \& Thun MJ 2001 Estrogen replacement therapy and ovarian cancer mortality in a large prospective study of US women. Journal of the American Medical Association 285 1460-1465.

Roger P, Sahla ME, Makela S, Gustafsson JA, Baldet P \& Rochefort H 2001 Decreased expression of receptor beta protein in proliferative preinvasive mammary tumors. Cancer Research $612537-2541$.

Rossouw JE, Anderson GL, Prentrice RL, LaCroix AZ, Kooperberg C, Stefanick ML, Jackson RD, Beresford SA, Howard BV, Johnson KC, Kotchen JM \& Ockene J Writing Group for Women's Health Institute Investigators 2002 Risks and benefits of estrogen plus progestin in healthy postmenopausal women: principal results from the Women's Health Initiative Randomized Controlled Trial. Journal of the American Medical Association 288 321-333.

Rutherford T, Brown WD, Sapi E, Aschkenazi S, Munoz A \& Mor G 2000 Absence of estrogen receptor-beta expression in metastatic ovarian cancer. Obstetrics and Gynecology 96 $417-421$.

Sabbah M, Courilleau D, Mester J \& Redeuilh G 1999 Estrogen induction of the cyclin D1 promoter: involvement of a cAMP response-like element. PNAS 96 11217-11222.

Santti R, Newbold RR, Makela S, Pylkkanen L \& McLachlan JA 1994 Developmental estrogenization and prostatic neoplasia. Prostate 24 67-78.

Sapi E, Brown WD, Aschkenazi S, Lim C, Munoz A, Kacinski BM, Rutherford T \& Mor G 2002 Regulation of Fas ligand expression by estrogen in normal ovary. Journal of the Society for Gynecologic Investigation 9 243-250.

Saville B, Wormke M, Wang F, Nguyen T, Enmark E, Kuiper G, Gustafsson JA \& Safe S 2000 Ligand-, cell-, and estrogenreceptor subtype (alpha/beta)-dependent activation at GCrich (Sp1) promoter elements. Journal of Biological Chemistry 275 5379-5387. 
Shaw JA, Udokang K, Mosquera JM, Chauhan H, Jones JL \& Walker RA 2002 Estrogen receptors alpha and beta differ in normal human breast and breast carcinomas. Journal of Pathology 198 450-457.

Skliris GP, Munot K, Bell SM, Carder PJ, Lane S, Hoirgan K, Lansdown MRJ, Parkes A, Hanby AM, Markham AF \& Speirs V 2003 Reduced expression of oestrogen receptor $\beta$ in invasive breast cancer and its re-expression using DNA methyl transferase inhibitors in a cell line model. Journal of Pathology 201 213-220.

Speirs V, Malone C, Walton DS, Kerin MJ \& Atkin SL 1999 Increased expression of estrogen receptor $\beta$ mRNA in tamoxifen-resistant breast cancer patients. Cancer Research $595421-5424$.

Stauffer SR, Coletta CJ, Tedesco R, Nishiguchi G, Carlson K, Sun J, Katzenellenbogen BS \& Katzenellenbogen JA 2000 Pyrazole ligands: structure-affinity/activity relationships and estrogen receptor- $\alpha$-selective agonists. Journal of Medicinal Chemistry 43 4934-4947.

Stossi F, Barnett DH, Frasor J, Komm B, Lyttle CR \& Katzenellenbogen BS 2004 Transcriptional profiling of estrogen-regulated gene expression via estrogen receptor $\alpha$ or estrogen receptor $\beta$ in human osteosarcoma cells: distinct and common target genes for these receptors. Endocrinology $1453473-3486$.

Strom A, Hartman J, Foster JS, Kietz S, Wimalasena J \& Gustafsson JA 2004 Estrogen receptor $\beta$ inhibits 17 $\beta$ estradiol-stimulated proliferation of the breast cancer cell line T47D. PNAS 101 1566-1571.

Sun J, Meyers MJ, Fink BE, Rajendra R, Katzenellenbogen JA \& Katzenellenbogen BS 1999 Novel ligands that function as selective estrogens or antiestrogens for estrogen receptor- $\alpha$ or estrogen receptor- $\beta$. Endocrinology 140 800-804.

Takeshita A, Cardona GR, Koibuchi N, Suen CS \& Chin WW 1997 TRAM-1, a novel 160-kDa thyroid hormone receptor activator molecule, exhibits distinct properties from steroid receptor coactivator-1. Journal of Biological Chemistry 272 27629-27634.

Tora L, White J, Brou C, Tasset D, Webster N, Scheer E \& Chambon P 1989 The human estrogen receptor has two independent nonacidic transcriptional activation functions. Cell 59 477-487.

Tremblay GB, Tremblay A, Copeland NG, Gilbert DJ, Jenkins NA, Labrie F \& Giguere V 1997 Cloning chromosomal localization, and functional analysis of the murine estrogen receptor beta. Molecular Endocrinology 11 353-365.

Tremblay GB, Tremblay A, Labrie F \& Giguere V 1999 Ligandindependent recruitment of SRC-1 by estrogen receptor $\beta$ through phosphorylation of activation function AF-1. Molecular Cell 3 513-519.

Vanacker JM, Pettersson K, Gustafsson JA \& Laudet V 1999 Transcriptional targets shared by estrogen receptor-related receptors (ERRs) and estrogen receptor (ER) alpha, but not by ERbeta. EMBO Journal 18 4270-4279.

Waliszewski P, Blaszczyk M, Wolinska-Witort E, Drews M, Snochowski M \& Hurst RE 1997 Molecular study of sex steroid receptor gene expression in human colon and in colorectal carcinomas. Journal of Surgical Oncology 64 3-11.

Warnmark A, Almlof T, Leers J, Gustafsson JA \& Treuter E 2001 Differential recruitment of the mammalian mediator subunit TRAP220 by estrogen receptors ERalpha and ERbeta. Journal of Biological Chemistry 29 23397-23404.

Watanabe T, Inoue S, Ogawa S, Ishii Y, Hiroi H, Ikeda K, Orimo A \& Muramatsu M 1997 Agonistic effect of tamoxifen is dependent on cell type, ERE-promoter context, and estrogen receptor subtype: functional difference between estrogen receptors alpha and beta. Biochemical and Biophysical Research Communications 236 140-145.

Webb P, Lopez GN, Uht RM \& Kushner PJ 1995 Tamoxifen activation of the estrogen receptor/AP-1 pathway: potential origin for the cell-specific estrogen-like effects of antiestrogens. Molecular Endocrinology 9 443-456.

Webb P, Valentine C, Nguyen P, Price RH Jr, Marimuthu A, West BL, Baxter JD \& Kushner PJ 2003 ERbeta binds NCoR in the presence of estrogens via an LXXLL-like motif in the N-CoR C-terminus. Nuclear Receptor 284.

Weihua Z, Saji S, Makinen S, Cheng G, Jensen EV, Warner M \& Gustafsson JA 2000 Estrogen receptor (ER) beta, a modulator of ERalpha in the uterus. PNAS 23 5936-5941.

Weihua Z, Makela S, Andersson LC, Salmi S, Saji S, Webster I, Jensen EV, Nilsson S, Warner M \& Gustafsson JA 2001 A role for estrogen receptor $\beta$ in the regulation of growth of the ventral prostate. PNAS 98 6330-6335.

Weyant MJ, Carothers AM, Mahmoud NN, Bradlow L, Remotti H, Bilinski RT \& Bertagnolli MM 2001 Reciprocal expression of $E R \alpha$ and $E R \beta$ is associated with estrogen-mediated modulation of intestinal tumorigenesis. Cancer Research $\mathbf{6 1}$ 2547-2551.

White R, Sjoberg M, Kalkhoven E \& Parker MG 1997 Ligandindependent activation of the oestrogen receptor by mutation of a conserved tyrosine. EMBO Journal 16 1427-1435.

Windahl SH, Hollberg K, Vidal O, Gustafsson JA, Ohlsson C \& Andersson G 2001 Female estrogen receptor beta ${ }^{-/-}$mice are partially protected against age-related trabecular bone loss. Journal of Bone and Mineral Research 16 1388-1398.

Young J, Legget B, Gustafson C, Ward M, Searle J, Thomas L, Buttenshaw R \& Chenevix-Trench G 1993 Genomic instability occurs in colorectal carcinomas but not in adenomas. Human Mutation 2 351-354.

Zhao C, Lam WFE, Sunters A, Enmark E, Tamburo De Bella M, Coombes RC, Gustafsson JA \& Dahlman-Wright K 2003 Expression of estrogen receptor $\beta$ isoforms in normal breast epithelial cells and breast cancer: regulation by methylation. Oncogene 22 7600-7606. 